\title{
Teachers Clinical Supervision Model at Elementary School 11 Langsa City of Aceh Province
}

\author{
Husaini \\ Department of Education Management \\ State University Of Medan \\ Medan, Indonesia \\ Corresponding email: husaini_17101969@yahoo.co.id
}

\begin{abstract}
Clinical Supervision was a service system to assist in improving the quality of teachers' trust, that there was significant progress in carrying out his professional duties as a teacher. The unwillingness of teachers to be clinically supervised by school supervisors became a fundamental problem at the level of basic education units. This study aimed to find the Clinical Supervision Model at Elementary School 11 Langsa City in order to overcome the unwillingness of teachers when being supervised by the school supervisor due to difficulties with various reasons experienced by teachers, feelings of fear, not mastering the model and learning strategy. The research method used was descriptive qualitative research method using Guba \& Lincoln and Miles \& Huberman scale namely by using observation and interview and documentation. This research was conducted in February 2016 January 2017 at Elementary School 11 Langsa City of Aceh Province. The result of the research showed that; a) the competence of teachers in Elementary School 11 Langsa City, owned ; (1) Pedagogic Competence of 60\%, (2) personality competence of $70 \%$,(3) social competence of $80 \%$, (4) professional competence of $60 \%$. so the teachers expressed the feelings of fear if being directly supervised into the classroom by supervisors, b) the researcher found a model of clinical supervision in Elementary School 11 Langsa City namely Instructional Observation through CCTV 2) Continuous Evaluation. The findings of this model would improve the professionalism of teachers in the implementation of learning in Elementary School 11 Langsa City.
\end{abstract}

Keywords - Model of clinical supervision, teacher.

\section{INTRODUCTION}

A variety of learning problems that people often complained about, such as the low interest of teachers in teaching, the inability of teachers to overcome difficulties in preparing various documents of learning, the difficulties of teachers in carrying out teaching tasks using teaching skills in accordance with the demands of the subject matter, there were teachers who always missed the information about the renewal of the field of learning, lack of coordination among colleagues, ineffective learning models and strategies and other problems related to learning.
Sagala (2012.p.193) On the other hand, there was an understanding among teachers that supervisory activities that were conducted by both school supervisors and principals (1) identified with the evaluation, so teachers tended to feel restless but they accepted the supervision because it was a program of their superiors; (2) the nature of the implementation of supervision so far was to look for the weaknesses of teachers, so that teachers felt anxious when they were visited by supervisors; (3) supervisors' supervisory objective was too broad and general in nature so it was difficult to provide directional feedback and useful for student learning in the classroom; (4) the feedback was just a briefing that put the power forward, even a series of threatening instructions, and did not involve the teacher in analyzing himself to find ways to develop himself and found no way to overcome teachers' difficulties in teaching; and (5) supervisors rarely monitored the existence of teaching and learning in the classroom, relied solely on document reports provided by teachers [1]

\section{A. The Meaning of Clinical Supervision}

Clinical Supervision as an instructional system that described the behavior of supervisors that related directly to teachers or groups of teachers to provide support, help and serve teachers to improve teacher work in educating the students.

1) The Characteristics of Clinical Supervision.The fundamental characteristic of clinical supervision according to the study of Acheson and Gall (1987: 14) is (1) improving the quality of intellectual skills and teacher-specific teaching behavior; (2) supervision should be responsible for helping teachers to develop (a) the skills of analyzing the learning process based on correct and systematic data (b) skilled in experimenting, adapting, and modifying the curriculum, and (c) to be more skilled at using teaching techniques, teachers had to practice over and over again; (3) supervision emphasized what and how teachers teach to improve the quality of learning, not to change the teacher's personality; (4) planning and analysis centered on the production and testing 
of learning hypotheses based on the evidence of observations; (5) conferences dealt with a number of important issues about learning that were relevant for teachers to change; (6) conferences as feedback focused on constructive analysis and reinforcement of successful patterns rather than blaming failed patterns; (7) the observations were based on evidence, not on substantial value judgments or incorrect decision judgments; (8) the cycle of planning, analysis and observation were sustainable and cumulative; (9) supervision was a dynamic giving and receiving process whereby supervisors and teachers were colleagues who researched to find mutual understanding in the field of education; (10) the supervision process was basically centered on learning analysis; (11) individual teachers had the freedom and responsibility to analyze and assess issues, improved the quality of teaching and developed the teacher's personal teaching style; (12) the process of supervision could be accepted, analyzed and developed more similarly to the state of teaching that could be done; and (13) a supervisor had the freedom and responsibility to analyze his or her supervisory activities in the same way as the teacher's evaluation analysis of his learning [2].

2) Clinical Supervision Focus School supervisors and principals who carried out clinical supervision, needed to understand clearly the direction and focus of Clinical supervision. The focus of clinical supervision was the improvement of the way teachers perform teaching tasks using more interactive models and strategies and making learners learn instead of changing the teacher's personality. Then the focus of clinical supervision was on the problem of teaching in a number of skills that were not too much, had vital meaning for education, were within intellectual reach and could be changed if necessary. The results of clinical supervision practice with clear direction and focus were then carried out constructive analysis by reinforcement of successful behavioral patterns rather than "denouncing" or "punishing" unsuccessful patterns or behaviors.

3) The Purpose of Clinical Supervision. The main purpose of the expected clinical supervision according to Cogan (1973: 12) was to produce professionally and responsible teachers and had a high commitment to improve oneself over the help of others [3]. Goldhammer, Anderson, Krajewski (1980.p.4) described the goals of clinical supervision as for instructional enhancement and learning outcomes. The goals to be achieved in the practice of clinical supervision by Goldhammer, Anderson, Krajewski (1980: 186) were to improve the quality of instructional and learning quality of learners so as to produce high learning quality through practice [4].

Improving instructional quality through the practice of clinical supervision was a basic necessity of professionalism. Improving the quality of this learning was necessary because the context of practice could change the quality of learning services constantly (Lovell and Wiles, 1983: 170) [5]. The purpose of clinical supervision, also collectively demanded the relationship between teachers and supervisors in which teachers had full control and responsibility about teaching and learning situations. Basically the general purpose of clinical supervision was (1) putting the pressure on the process of "professional formation and development"; (2) responding to the main understanding and needs of the teacher associated with the task: (3) supporting educational reform and to "combat" the decline ": (4) the students could learn well so that the goals of education and teaching could be achieved optimally: (5) the key to improving the professional skills of teachers.

\section{B. Clinical Supervision Process}

Clinical Supervision was a dynamic giving and receiving process. In this case supervisors and teachers were peers and seeking a common understanding related to education. The process of clinical supervision primarily centered on verbal interactions regarding the analysis of the course of instruction. Each teacher had the freedom and responsibility to raise the subject matter, taught it himself. And develop his teaching style. Then the supervisor had the freedom and responsibility to analyze and evaluate his own way of supervision by analyzing and evaluating the teachers' way of teaching. Oliva (1984.p.202) argues that basically the clinical supervision activities consist of planning to observe teachers while teaching, observing when teachers teach, and analyzing the results of teacher teaching observations [6].

\section{The Problem of Clinical Supervision Implementation}

Clinical Supervision was a service system that helped to improve teachers' confidence that there was significant progress in performing their professional duties as teachers. Sometimes supervisors and teachers also found the difficulties to implement ideas in education. These difficulties can occur for various reasons such as inadequate insight and supervisory skills in practicing clinical supervision. Then the unwillingness of teachers to be supervised happened because they did not master the model and learning strategy, and did not have a learning document and so on. Another reason was inadequate support from school principals and policy makers in local governments where the supervisor was located. All of these reasons were difficulty factors in the implementation of clinical supervision, but the underlying problem was the weakness in the school supervisor and the teacher.

More academic problems of clinical supervision problems included (1) some organizations were interested in clinical supervision but had no ability in terms of material and human resources; (2) some organizations made assumptions that all teachers needed to have ongoing clinical supervision; (3) in some organizations the supervisors lacked skills and understanding of clinical supervision; (4) in clinical supervision, teachers needed certain skills and understanding; (5) some organizations were unable to use clinical supervision as a system for evaluating teachers; (6) clinical supervision was sometimes used in a series of steps that were not flexible and rigorous, which should not consider the needs and readiness of a teacher such as observation and analysis study, feedback, and correction procedures; (7) sometimes the supervisors did not have the ability to trust each other; (8) sometimes supervisors thought that the way they observed was the right situation; and (9) fears often haunted teachers. Academically, the implementation of clinical supervision 
could improve the quality of learning services received by learners.

The steps that had been done by the government, namely, by assigning further study / learning tasks to the school supervisors who were still stratified S1 to be S2. The goal was that the supervisor who would be assigned to the field had the competence that was expected so that the goals of the organization could be achieved well. The researcher's solution to solve the teacher's fear problem in clinical supervision was using observational supervision model through CCTV and continuous evaluation.

\section{METHODS AND RESULTS}

\section{A. Methods}

The research method used was descriptive qualitative research method using Guba \& Lincoln and Miles \& Huberman scale. Data collection techniques was by using observation, interview and documentation. This research was conducted in February 2016 - January 2017 at State Elementary School 11 Langsa City of Aceh Province.

\section{B. Results}

Table 1

Components of Clinical Supervision Pedagogic Competencies

\begin{tabular}{|l|l|l|c|}
\hline \multirow{2}{*}{ No. } & \multicolumn{2}{|c|}{ Components of Clinical Supervision } & \multirow{2}{*}{$(\%)$} \\
\cline { 2 - 3 } & $\begin{array}{l}\text { Pedagogic Competencies } \\
\text { Materials }\end{array}$ & $\begin{array}{l}\text { Not Knowing Learning } \\
\text { Strategies }\end{array}$ & \multirow{2}{*}{$60 \%$} \\
\hline 1. & $40 \%$ & $20 \%$ & \\
\hline
\end{tabular}

Table 1. above showed that teachers at Elementary School 11 Langsa who had Pedagogical competence were 60\%, teachers who did not master the teaching materials were $40 \%$ while teachers who did not understand / did not know the learning strategy were $20 \%$, the meaning of the data above assumed that teachers who had pedagogic competence in Elementary School 11 Langsa only had minimal/enough ability of understanding to learners. Not mastering teaching materials and learning strategies by a teacher then the goals expected by the organization / unit of education were not achieved effectively and efficiently.

Table 2

Components of Clinical Supervision Personality Competence

\begin{tabular}{|c|c|c|c|}
\hline \multirow{3}{*}{ No. } & \multirow{2}{*}{\multicolumn{2}{|c|}{$\begin{array}{c}\text { Components of Clinical Supervision } \\
\text { Personality Competence }\end{array}$}} & \multirow{2}{*}{$(\%)$} \\
\hline & & & \\
\hline & $\begin{array}{l}\text { Feelings of Fear in } \\
\text { Supervision }\end{array}$ & $\begin{array}{l}\text { Not Willing to be } \\
\text { Supervised }\end{array}$ & \multirow[t]{2}{*}{$70 \%$} \\
\hline 1. & $45 \%$ & $25 \%$ & \\
\hline
\end{tabular}

Table 2. above showed that teachers in Elementary School 11 Kota Langsa who had a personality competency were $70 \%$, teachers who felt fear when being supervised by supervisors were $45 \%$, while teachers who were unwilling to be supervised by supervisors were $25 \%$, the meaning of the data above assumed that teachers who had personality competencies in Elementary School 11 Langsa City were very low or did not have a good confidence. This also affected the goals expected by the organization / unit of education could not be achieved effectively and efficiently.

Table 3

Components of Clinical Supervision Social Competence

\begin{tabular}{|l|c|c|c|}
\hline \multirow{3}{*}{ No. } & \multicolumn{2}{|c|}{ Components of Clinical Supervision } & \multirow{2}{*}{$(\%)$} \\
\cline { 2 - 3 } & \multicolumn{2}{|c|}{ Social Competence } & \multirow{2}{*}{$80 \%$} \\
\cline { 2 - 3 } & Prefer to supervision & $\begin{array}{c}\text { Prefer to promotion / } \\
\text { consultation }\end{array}$ & \multirow{2}{*}{$80 \%$} \\
\hline 1. & $35 \%$ & $45 \%$ & \\
\hline
\end{tabular}

Table 3 above showed that teachers in Elementary School 11Langsa City who had social competence were $80 \%$, teachers who preferred to be supervised were $35 \%$, while teachers who preferred to be promoted / consulted were $45 \%$, the meaning of the data table 5 above assumed that teachers who had social competence in Elementary School 11 Langsa were good enough. Social competencies possessed by teachers were expected to achieve the goals expected by the organization / unit of education effectively and efficiently.

Table 4

Components of Clinical Supervision Professional Competence

\begin{tabular}{|l|c|c|c|}
\hline \multirow{2}{*}{ No. } & \multicolumn{2}{|c|}{ Components of Clinical Supervision } & \multirow{2}{*}{$(\%)$} \\
\cline { 2 - 3 } & \multicolumn{2}{|c}{ Professional Competence } & \multirow{2}{*}{$60 \%$} \\
\cline { 2 - 3 } & Provide Useful Learning & Discipline In Teaching & \\
\hline 1. & $25 \%$ & $35 \%$ & \\
\hline
\end{tabular}

Table 4 above showed that teachers in Elementary School 11 Langsa City who had professional competence were $60 \%$, from the observation results obtained that teachers who provided useful learning for students were $25 \%$, while teachers who were discipline in teaching were $25 \%$, the meaning of the data table 6 above assumed that teachers who had professional competence in Elementary School 11 Langsa were still not good enough / low. This would affect the goals expected by the organization / unit of education were not achieved effectively and efficiently.

\section{FINDING AND DISCUSSION}

\section{A. Discussion}

Based on Law Number 14 of 2005 concerning on Teachers and Lecturers, in article 10 paragraph (1) stated that "Teacher competence as referred to in Article 8 covered pedagogic competence, personality competence, social competence, and professional competence obtained through professional education" Teacher competency standards included core teacher competencies developed into PAUD / TK / RA teacher competencies, teacher of SD / MI, and subject teachers/MI, SMP/MTs, SMA/MA, and SMK/MAK.

1) Pedagogic Competencies. Pedagogic competence was the ability to understand the learners, to design and implement the learning, to evaluate learning outcomes, and to develop the 
learners to actualize their potentials. Sub competences in Pedagogic competence were:

a) Understanding learners in depth. Which included understanding learners by utilizing the principles of cognitive development, the principles of personality, and identify the initial learning of the learners.

b) Designing lessons, including understanding the educational foundation for learning interests that included understanding of the educational foundation, applying the theory of teaching and learning, determining learning strategies based on the characteristics of learners, the competencies to be achieved, and teaching materials, as well as preparing the design of learning based on selected strategies.

c) Carrying out learning, that included setting the learning setting and conducting a conducive learning.

d) Designing and implementing learning evaluations, that included designing and conducting continuous evaluation of processes and learning outcomes with a variety of methods, analyzing the results of process evaluation and learning outcomes to determine the level of mastery learning (mastery level), and utilizing the results of the assessment of learning to improve the quality of the general learning program.

e) Developing learners to actualize their various potentials, included facilitating the learners for the development of various academic potentials, and facilitating the learners to develop various non-academic potentials.

2. Personality Competence. Personality Competence was a personal ability that reflected a steady, stable, mature, wise and authoritative personality, became a role model for learners, and had a noble character. Sub competencies in personality competence included:

a) A stable personality, included acting in accordance with social norms, proud to be a teacher, and had consistency in acting in accordance with the norm.

b) Amature personality, was to show the independence in acting as an educator and had a work ethic as a teacher.

c) A wise personality, was to display the actions based on the usefulness of learners, schools and communities and to show openness in thinking and acting.

d) Authoritative personality, included having behaviors that positively affected the learners and had a respected behavior.

e) Be noble and could be an example, include acting in accordance with religious norms (faith, honest, sincere, helpful) and had exemplary behavior for learners.

3. Social Competence. Social Competence was the ability of teachers to communicate and get along effectively with learners, education personnel, parents / trustees of learners, and the community around.

a) Being incultive, acting objectively, and not discriminating, due to gender considerations, religion, race, physical condition, family background, and family social status. b) Communicate effectively, empathically, and courteously, with fellow educators, education personnel, parents and community.

c) Adaptable in place of duty throughout the territory of the Republic of Indonesia which had a diversity of social culture.

\section{d) Communicate orally and in writing}

4. Professional Competence, Professional competence was the mastery of learning materials widely and deeply, which included mastery of curriculum material subjects in schools and scientific substances that overshadowed the material, as well as the mastery of the structure and scientific methodology.

a) Mastering the materials, structure, concepts, and scientific mindset that supported the lessons being taught.

b) Mastering the standard of competence and basic competence of subject / field of development that was taught

c) Developing the learning materials, that were taught creatively.

d) Developing the professionalism in a sustainable manner by taking reflective action.

e) Utilizing ICT, to communicate and develop.

\section{B. Finding}

From the description of the results \& discussion, and associated with the competence of classroom teachers in Elementary School 11 Langsa City, there were interesting findings. Some indeed proved the theory of the four models of clinical supervision of experts (Goldhammer (1969), Anderson and Krajewski (1980), et al) namely classroom teachers carried out the steps of their theory. However, the data in the field did not prove another theory principle, but most classroom teachers admitted that supervision by school supervisors would make teachers express feelings of fear if they were directly supervised into the classroom by supervisors. This was due to their unpreparedness in terms of preparing the learning. From this description, then one model of clinical supervision at Elementary School 11 Langsa was found, namely; 1) Instructional observation through CCTV 2) Continuous Evaluation. The findings of this model would improve the professionalism of teachers in the implementation of learning in Elementary School 11 Langsa City.

\section{CONCLUSION}

This research could be concluded that; From the research findings, it was known that, the competence of teachers at Elementary School 11 Langsa City; 
1) Pedagogic Competence was $60 \%$.

2) personality competence was $70 \%$.

3) social competence was $80 \%$.

4) professional competence was $60 \%$, so teachers expressed feelings of fear if they were directly supervised into the classroom by the supervisor.

From the findings of this research, one model of clinical supervision at elementary school 11 Langsa city was found, namely :

\section{1) Instructonal Observation Through CCTV.}

2) Continuous Evaluation.

The findings of this model would improve the professionalism of teachers In the implementation of learning in elementary school 11 Langsa City.

\section{Acknowledgment}

We thank the principals for their assistance at various stages of development and validation of this assessment, and have also provided data from Elementary School 11 Langsa City Aceh Province

\section{References}

[1] Sagala.H.S., 2012. "Supervision of Learning In Education Professional," Bandung: Alfabeta

[2] Acheson,K.A and Gall. "Techniques in the Clinical Supervision of Teacher, second edition, White Palin, New York: Longman.

[3] Cogan. 1973. Clinical Supervision: Conceptual Framework in Jurnal of research and Development in Education- Vol.15. Number 2

[4] Goldhammer,R.,Anderson,R.H， \& Krajewski,R.J.1980. Clinical supervision: "Special methods for the supervision of teachers," 2 nd Ed.New-York: Holtl Rinehart Wiston.

[5] Lovell, Jhon \& Wiles Kimball. 1983. Supervision For Better Schools : Fifth Edition. New Jersey : Prentice-Hall, Inc.

[6] Oliva,P.F.,1984. "Supervision for Better School, London: Longman 